\title{
ANALISIS DAN PERBANDINGAN ANTARA UUD 1945, KONSTITUSI RIS, UUDS 1950 DAN UUD 1945 AMANDEMEN. SUBSTANSI, KOMPARASI DAN PERUBAHAN YANG PENTING
}

\author{
Novita Mandasari Hutagaol \\ Dosen Tetap Prodi Pendidikan Sejarah - FKIP UNRIKA
}

\begin{abstract}
Abrastrak
Pengalaman panjang bangsa Indonesia yang pernah dijajah bangsa asing menjadi sebuah pelajaran berharga bagi para pendiri bangsa. Oleh sebab itu untuk menjaga bangsa Indonesia dari pendudukan kembali bangsa asing dirumuskanlah undang-undang dasar yang isinya berpihak terhadap kepentingan rakyat, bangsa, dan negara. Indonesia terus berbenah diri menjadi negara yang demokrasi. Panitia Persiapan Kemerdekaan Indonesia (PPKI) mensahkan berlakunya Undang-Undang Dasar pada tanggal 18 Agustus 1945 yang selanjutnya dikenal sebagai Undang-Undang Dasar 1945 (UUD 1945). Undang-undang dasar dibuat/dirumuskan sesuai dengan kondisi rakyat Indonesia karena tujuannya adalah untuk kesejahteraan seluruh rakyat Indonesia.
\end{abstract}

\section{A. Pendahuluan}

Indonesia adalah salah satu negara di dunia yang memiliki catatan sejarah yang cukup panjang dalam mencapai sebuah kemerdekaan. Dimulai dari masa Kerajaan Sriwijaya, Majapahit hingga Mataram sampai kepada penjajahan Belanda dan pendudukan Jepang. Penjajahan Belanda mengeksploitasi bidang politik, sosial budaya hingga ekonomi bangsa, hal ini menjadikan rakyat Indonesia haus akan sebuah kemerdekaan. Perlawanan terus dilakukan bangsa Indonesia untuk merebut kembali tanah pertiwi yang dieksploitasi bangsa asing hingga robohnya pemerintahan penjajahan Hindia Belanda tahun 1942. Kemudian masuknya pendudukan Jepang dengan alibi ingin "menolong" bangsa Indonesia. Kata-kata "menolong" menjadi sama prakteknya dengan "menjajah" yang dilakukan Belanda. Kondisi ini dibaca oleh kaum-kaum intelektual pada saat itu sehingga dimulailah kembali perlawanan, perjuangan mengusir penjajahan Jepang. Kemudian Jepang menjanjikan kemerdekaan dengan membentuk sebuah Badan Penyelidik Usaha-usaha Persiapan Kemerdekaan Indonesia (BPUPKI). Adapun tugas dari badan ini adalah mempelajari hal-hal yang diperlukan untuk menyelenggarakan suatu negara merdeka. Tanggal 29 April dibentuklah Badan Penyelidik Usaha-usaha Persiapan 
Kemerdekaan Indonesia (BPUPKI) dengan 62 orang anggota. Kemudian pada tanggal 17 Agustus di proklamirkan kemerdekaan bangsa Indonesia.

Bentuk pemerintahan Indonesia adalah "Republik" dengan kepala pemerintahan presiden. Sebuah negara haruslah memiliki dasar negara, presiden dan wakil presiden. Pada tanggal 18 Agustus 1945 melalui Panitia Persiapan Kemerdekaan Indonesia (PPKI) disahkanlah Soekarno menjadi presiden dan Hatta menjadi wakil presiden. Pergolakan politik terus terjadi, Indonesia terus berbenah diri membentuk negara yang tujuannya untuk kesejahteraan rakyat banyak. Indonesia terus mengalami proses perjalanan membentuk negara yang demokrasi. Perubahan praktek ketatanegaraan dan sistem pemerintahan kemudian meletakkan Undang-undang Dasar Negara yang bersifat "sementara" yang dikenal dengan UUD 1945, Konstitusi RIS, UUDS 1950 hingga kembalinya kepada UUD 1945 sampai sekarang yang pada saat ini juga mengalami amandemen. Undang-Undang Dasar dibentuk berdasarkan kebutuhan perkembangan zaman.

\section{B. Undang-Undang Dasar 1945}

Panitia Persiapan Kemerdekaan Indonesia (PPKI) mensahkan berlakunya UndangUndang Dasar pada tanggal 18 Agustus 1945 yang selanjutnya dikenal sebagai UndangUndang Dasar 1945 (UUD 1945). Undang-Undang Dasar 1945 sendiri rancangannya dibuat oleh Badan Penyelidik Usaha-usaha Persiapan Kemerdekaan Indonesia (BPUPKI) yang pada saat itu dipimpin oleh dr. Radjiman Wedyodiningrat. ${ }^{1}$ Undang-Undang 1945 ini diumumkan secara resmi dalam berita Republik Indonesia tanggal 15 Februari 1946 Tahun ke II No.7.

Rumusan tata cara perubahan Undang-Undang Dasar 1945 diatur dalam Pasal 37, dengan rumusan :

1. Untuk mengubah undang-undang dasar sekurang-kurangnya $2 / 3$ dari pada jumlah anggota Majelis Permusyawaratan Rakyat harus hadir;

2. Putusan diambil dengan persetujuan sekurang-kurangnya $2 / 3$ daripada jumlah anggota yang hadir.

Dari ketentuan di atas maka secara teoritis Undang-Undang Dasar 1945 sulit diubah karena membutuhkan persetujuan mayoritas mutlak (2/3) anggota yang hadir dan yang hadir harus mayoritas mutlak (2/3 dari seluruh anggota Majelis Permusyawaratan Rakyat (MPR). Majelis Permusyawaratan Rakyat (MPR) adalah lembaga permusyawaratan yang anggotanya

${ }^{1}$ Ricklefs. Sejarah Indonesia Moderen 1200 -2004 (Jakarta: Serambi, 2005), hlm. 471-472. 
terdiri dari seluruh anggota DPR ditambah dari utusan daerah dan utusan golongan. Oleh karena itu untuk mengubah Undang-Undang Dasar 1945 memerlukan prosedur yang panjang karena lembaga yang anggotanya banyak dan terdiri dari beranekaragam daerah, golongan fungsional, sehingga Undang-Undang Dasar 1945 dapat disebut undang-undang dasar yang kaku.

Undang-Undang Dasar hanya memuat 37 pasal, pasal-pasal lain hanya memuat peralihan dan tambahan. Undang-Undang Dasar 1945 adalah undang-undang yang cukup singkat dan bersifat umum yang hanya memuat aturan-aturan pokok, memuat garis-garis besar sebagai instruksi kepada pemerintah pusat untuk menyelenggarakan kehidupan negara dan kesejahteraan sosial. Hal ini disadari oleh para pembuat Undang-Undang Dasar 1945, disebutkan dalam penjelasan dengan bunyi "UUD hanya terdiri dari 37 pasal. Pasal-pasal lain hanya memuat peralihan dan tambahan. Maka rencana ini sangat singkat jika dibandingkan dengan Undang-Undang Dasar Philipina. Maka telah cukup jikalau undang-undang dasar hanya memuat aturan-aturan pokok, hanya memuat garis-garis besar sebagai instruksi kepada pemerintah pusat dan lain-lain penyelenggara negara untuk menyelenggarakan kehidupan negara dan kesejahteraan sosial. Terutama bagi negara baru dan negara muda, lebih baik hukum dasar yang tertulis itu hanya memuat aturan-aturan pokok, sedang aturan-aturan yang menyelenggarakan aturan pokok itu diserahkan kepada undang-undang yang lebih mudah cara membuat, merubah dan mencabut. Demikianlah sistem undang-undang dasar.

Kita harus senantiasa ingat kepada dinamika kehidupan masyarakat dan negara Indonesia. Masyarakat dan negara Indonesia berkembang terus, zaman berubah, Zaman berevolusi sehingga menghasilkan kondisi negara yang saat ini masuk kepada masa reformasi. Oleh karena itu, kita harus hidup secara dinamis, harus melihat gerak-gerik kehidupan masyarakat dan negara Indonesia. Berhubung dengan itu, janganlah tergesa-gesa memberi kristalisasi, memberi bentuk (Gestaltung) kepada pikiran-pikiran yang masih mudah berubah.

Memang sifat aturan yang tertulis itu mengikat. Oleh karena itu, makin "supel" (elastic) sifat aturan itu makin baik. Jadi kita harus menjaga supaya sistem undang-undang dasar jangan sampai ketinggalan zaman. Jangan sampai kita membuat undang-undang yang lekas usang (verouderd). Selain itu yang sangat penting dalam pemerintahan dan dalam hal hidupnya negara ialah semangat, semangat para penyelenggara negara, semangat para pemimpin pemerintahan. Meskipun dibuat undang-undang dasar yang menurut kata-katanya bersifat kekeluargaan, apabila semangat para penyelenggara negara, para pemimpin pemerintahan itu bersifat perseorangan, undang-undang dasar tadi dalam prakteknya tentu tidak ada artinya. Sebaliknya, meskipun undang-undang dasar itu tidak sempurna, akan tetapi jikalau semangat 
para penyelenggara pemerintahan baik, undang-undang dasar itu tidak akan merintangi jalannya negara. Oleh sebab itu yang paling penting ialah semangat kebangsaan. Semangat itu hidup, atau dengan kata lain dinamis. Berhubungan dengan itu, hanya aturan-aturan pokok saja harus ditetapkan dalam undang-undang dasar, sedangkan hal-hal yang perlu untuk menyelenggarakan aturan-aturan pokok itu harus diserahkan kepada undang-undang"2.

Dari ketentuan pada Aturan Tambahan UUD 1945 dapat disebutkan bahwa sifat dari UUD 1945 yang ditetapkan oleh PPKI hanya untuk sementara saja, Sebagaimana yang berbunyi:

1. Dalam enam bulan sesudah berakhirnya peperangan Asia Timur Raya, Presiden Indonesia mengatur dan menyelenggarakan segala hal yang ditetapkan dalam undang-undang dasar ini;

2. Dalam enam bulan sesudah Majelis Permusyawaratan Rakyat dibentuk, Majelis ini bersidang untuk menetapkan undang-undang dasar

Berakhirnya Perang Asia Timur Raya, Majelis Permusyawaratan Rakyat (MPR) belum juga terbentuk sesuai dengan keinginan Aturan Tambahan UUD 1945, ini dikarenakan Indonesia menghadapi perang dengan Belanda untuk mempertahankan kemerdekaan. Kondisi yang terjadi setelah berakhirnya perang, Negara Kesatuan Republik Indonesia (NKRI) berubah menjadi Republik Indonesia Serikat (RIS), sedangkan Negara Kesatuan Republik Indonesia (NKRI) sendiri menjadi salah satu Negara Bagian dari Republik Indonesia Serikat (RIS). Undang-Undang Dasar 1945 hanya berlaku di wilayah Negara Bagian Republik Indonesia saja. Berakhirnya Republik Indonesia Serikat (RIS) digantikan menjadi Negara Kesatuan Republik Indonesia (NKRI). Undang-Undang Dasar 1945 dan Konstitusi Republik Indonesia Serikat tidak berlaku. Keduanya diganti dengan Undang-Undang Dasar Sementara (UUDS) tahun 1950.

\section{Konstitusi Republik Indonesia Serikat (RIS) 1949}

Pada tanggal 17 Agustus 1945 Negara Republik Indonesia di proklamirkan kemerdekaannya. Ini disambut baik oleh segenap rakyat Indonesia, perjuangan dengan darah yang bercucuran menjadi sebuah rasa syukur karena kemerdekaan telah diraih. Sehingga keinginan untuk terus mempertahankan kemerdekaan tetap berkobar di dalam hati anak-anak

${ }^{2}$ Saragih, Bintan. Perubahan,Penggantian dan Penetapan Undang-Undang Dasar di Indonesia (Bandung: Utomo, 2006), hlm.21. 
bangsa. Keinginan Belanda untuk kembali menjajah Indonesia terus dilawan, menyadari akan hal itu Belanda mencoba menggunakan taktik lain dengan menjadikan Indonesia menjadi negara federal. Belanda ingin merebut kembali wilayah Republik Indonesia dengan menjadikannya hanya sebagai negara bagian saja. Dengan politik "federalisme" ini Belanda bermaksud memperlemah kedudukan RI. Belanda melakukan Agresi Militer I dan II dan melanggar perjanjian Renville yang telah disetujui bersama. Melihat itu maka Perserikatan Bangsa-Bangsa melakukan penyelesaian dengan mengadakan konfrensi yang disebut dengan Konfrensi Meja Bundar (KMB). Konfrensi ini dihadiri negara-negara bentukan Belanda yang tergabung dalam Byeenkomst voor Federal Overleg (BFO).

Kemudian didirikanlah Negara Republik Indonesia Serikat Pada tanggal 27 Desember 1949 dan mulai saat itu berlakulah konstitusi Republik Indonesia Serikat (RIS). Berlakunya Konstitusi Republik Indonesia Serikat (RIS) untuk wilayah negara bagian RIS maka UUD 1945 yang awalnya berlaku diseluruh wilayah Indonesia menjadi berlaku hanya dalam wilayah Republik Indonesia (RI) sebagai sebuah negara bagian dari RIS. Konstitusi RIS adalah sebuah konstitusi sementara karena menurut pasal 186 Konstitusi RIS "Konstituante (sidang pembuat Konstitusi) bersama-sama dengan Pemerintah selekas-lekasnya menetapkan Konstitusi Republik Indonesia Serikat (RIS) yang akan menggantikan Konstitusi sementara". Sifat sementara ini karena pembentuk Undang-Undang Dasar merasa belum representatif untuk menetapkan sebuah Undang-Undang Dasar, selain itu pembuatan undang-undang dasar ini dilakukan tergesa-gesa hanya untuk segera dibentuk memenuhi kebutuhan sehubungan akan dibentuknya Negara Federal. Oleh sebab itu menurut Konstitusi Republik Indonesia Serikat dikemudian hari akan dibentuk sebuah badan Konstituante yang bersama Pemerintah akan menetapkan Undang-undang Dasar yang baru sebagai Undang-undang Dasar yang tetap yaitu sebuah badan Konstituante.

Kekuasaan berkedaulatan didalam Negara Republik Indonesia Serikat adalah dilakukan oleh Pemerintah bersama-sama dengan Dewan Perwakilan Rakyat dan Senat (pasal 1 dan 2). Badan ini jugalah yang menjadi badan pembentuk undang-undang yaitu Dewan Perwakilan Rakyat saja tanpa ikut Senat. Pemerintah menurut Konstitusi Republik Indonesia Serikat adalah Presiden dengan seorang atau beberapa atau para menteri yakni menurut tanggung jawab khusus atau umum mereka (pasal 68 ayat 2). Dalam pasal 117 tugas penyelenggaraan pemerintah federal dijalankan oleh Pemerintah. Dalam penyelenggaraan pemerintahan negara, Presiden tidak dapat diganggu gugat tetapi tanggung jawab kebijaksanaan pemerintah adalah 
ditangan menteri-menteri baik secara bersama maupun masing-masing untuk bagiannya sendiri-sendiri (pasal 118). Dilihat dari hal itu maka Konstitusi Republik Indonesia Serikat digolongkan menganut sistem "kabinet parlementer"3. Sistem ini tidak bisa dikerjakan selama masa Konstitusi RIS, karena Dewan Perwakilan Rakyat yang belum didasarkan kepada pemilihan umum sesuai pasal 111, tetapi masih Dewan Perwakilan Rakyat yang ditunjuk atas dasar pasal 109 dan pasal 110 Konstitusi Republik Indonesia Serikat. Pasal 122 Konstitusi Republik Indonesia Serikat menentukan "Dewan Perwakilan Rakyat yang ditunjuk menurut pasal 109 dan 110 tidak dapat memaksa Kabinet atau masing-masing Menteri meletakkan jabatannya". Pasal 69 Konstitusi Republik Indonesia Serikat ditentukan bahwa kepala negara adalah Presiden yang dipilih oleh orang-orang yang dikuasakan oleh pemerintah bagian.

Pada tanggal 16 Desember 1949 diadakan pemilihan Presiden untuk Republik Indonesia Serikat, wakil-wakil dari pemerintah negara/daerah bagian (pasal 2). Dari hasil pemilihan ini terpilihlah Soekarno menjadi Presiden yang pada waktu itu masih menjadi Presiden Republik Indonesia. Kemudian untuk pertama kalinya Dewan Perwakilan Rakyat dibentuk berdasarkan pemilihan umum seperti yang dimaksud pada pasal 111, maka pembentukannya masih didasarkan pada pasal 109 dan pasal 110 Konstitusi Republik Indonesia Serikat. Pasal 109 menentukan :

1. Untuk Dewan Perwakilan Rakyat uang pertama, mengutus anggota-anggota dari daerah-daerah selebihnya yang tersebut dalam pasal 99, diatur dan diselenggarakan dengan perundingan bersama-sama oleh daerah-daerah bagian yang tersebut dalam pasal 2, kecuali Negara Republik Indonesia dengan memperhatikan asas-asas demokrasi dan seboleh-bolehnya dengan perundingan dengan daerah-daerah yang tersebut dalam pasal 2 sub c, yang bukan daerah bagian.

2. Untuk pembagian jumlah-jumlah anggota yang akan diutus diantara daerahdaerah itu, diambil sebagai dasar perbandingan jumlah jiwa rakyat daerahdaerah bagian tersebut.

Pasal 110 menentukan:

${ }^{3}$ Kabinet parlementer adalah pertanggung jawaban menteri apabila kebijaksanaan menteri/para menteri ternyata tidak dapat dibenarkan oleh Dewan Perwakilan Rakyat maka harus mengundurkan diri. 
1. Bagaimana caranya anggota diutus ke Dewan Perwakilan Rakyat yang pertama, diatur oleh daerah-daerah bagian.

2. Di mana pengutusan demikian tidak dapat terjadi dengan jalan pemilihan yang seumum-umumnya, pengutusan itu dapat dilakukan dengan jalan penunjukan anggota-anggota oleh perwakilan rakyat daerah-daerah bersangkutan, jika ada di situ perwakilan demikian.

Juga apabila, karena hal-hal yang sungguh, perlu diturut cara lain, yang diusahakan untuk mencapai perwakilan yang sesempurna-sempurnanya, menurut kehendak rakyat.

Pemilihan umum belum bisa diadakan untuk anggota-anggota Dewan Perwakilan Rakyat karena Konstitusi Republik Indonesia Serikat dirubah menjadi Undang-Undang Dasar Sementara. Disamping Dewan Perwakilan Rakyat ada Senat. Senat merupakan utusan-utusan yang mewakili negara/daerah bagian yang masing-masing negara/daerah bagian 2 orang (pasal $80)$.

\section{Undang-Undang Dasar Sementara 1950}

Sejak proklamasi Kemerdekaan bangsa Indonesia menginginkan negara Kesatuan bukan negara federal. Pembentukan Negara Republik Indonesia Serikat merupakan politik Belanda untuk memecah belah bangsa Indonesia. Negara federal tidak dapat memberikan kesejahteraan kepada rakyat sehingga rakyat terus melakukan perlawanan. Keinginan rakyat untuk menggabungkan diri dalam Republik Indonesia dan membentuk Negara Kesatuan terus diperjuangkan. Negara-negara bagian menggabungkan diri dengan Republik Indonesia, hanya 2 negara bagian yang tidak menggabungkan diri yaitu Negara Sumatera Timur (NST) dan Negara Indonesia Timur (NIT) meskipun akhirnya keduanya menggabungkan diri dalam Republik Indonesia.

Perundingan-perundingan dilakukan antara pemerintah Republik Indonesia Serikat (NST dan NIT) dengan pemerintah Republik Indonesia dengan tujuan membentuk negara Kesatuan. Maka pada tanggal 19 Mei 1950 ditandatanganilah piagam persetujuan antara Pemerintah RIS dan Pemerintah RI yang ditandatangani oleh masing-masing Perdana Menteri. Selanjutnya dibentuk sebuah Panitia Bersama yang tugas utama merancang UUDS Negara Kesatuan, pada saat itu diketuai oleh Soepomo (RIS) dan Mr. Abdul Hakim (RI). Pada tanggal 
30 Juni hasil dari Panitia Bersama disampaikan kepada Pemerintah RIS dan Pemerintah RI. Dengan merubah sedikit karya Panitia Bersama oleh kedua Pemerintah dijadikan Rancangan UUDS RI dan diajukan kepada DPR, Senat dan Banda kerja KNIP yang tanpa mengamandemen menjadikannya menjadi Undang-Undang Dasar Sementara (UUDS RI).

Pada tanggal 20 Juli 1950 Pemerintah RIS dan Pemerintah RI menyetujui Rancangan UUDS RI yang selanjutnya diteruskan ke DPR oleh Pemerintah dan kepada Badan Pekerja KNP oleh Pemerintah RI untuk memperoleh pengesahan. Presiden Soekarno menyatakan terbentuknya Negara Kesatuan Republik Indonesia pada tanggal 15 Agustus 1950 dihadapan Sidang Istimewa BP KNP Yogyakarta. UU Federal yang memuat naskah UUDS RI adalah UU No. 7/1950 (LN 1950/56) dan mulai berlaku tanggal 17 Agustus 1950 (pasal 11 ayat 1). Dengan begitu 17 Agustus 1950 kembalilah bangsa Indonesia ke Negara Kesatuan Republik Indonesia berdasarkan Proklamasi 1945. ${ }^{4}$

Perubahan-perubahan mendasar dalam pelaksanaan ketatanegaraan menurut ketetapan UUDS 1950 dapat dilihat dari uraian Piagam Persetujuan Pemerintah Republik Indonesia Serikat dan Pemerintah Republik Indonesia tanggal 19 Mei 19505:

a) Penghapusan Senat;

b) DPRS terdiri dari atas gabungan DPR Republik Indonesia Serikat dan Badan Pekerja KNIP. Tambahan anggota atas penunjukan Presiden dipertimbangkan lebih jauh oleh kedua pemerintah; (untuk pertama kalinya, selanjutnya diatur dalam Pasal $56,57,58,59,60$ dst.)

c) DPRS bersama-sama dengan KNIP dinamakan Majelis Perubahan Undang-Undang Dasar, mempunyai hak mengadakan perubahan-perubahan dalam undang-undang yang baru; (selanjutnya diatur pada Pasal 91,92 dst)

d) Konstituante terdiri dari anggota-anggota yang dipilih dengan mengadakan pemilihan umum berdasar atas satu orang anggota untuk tiap 300.000 penduduk, dengan memperhatikan perwakilan yang pantas bagi golongan minoriteit; (Pasal $135 \mathrm{dst})$

e) Presiden adalah Presiden Soekarno; (diatur selanjutnya pada Pasal 45)

f) Dewan Menteri harus bersifat kabinet parlementair; (Pasal 50,51,52 dst)

\footnotetext{
${ }^{4}$ Ricklefs, Op.Cit.

${ }^{5}$ Jimly Ashiddiqie, Format Kelembagaan Negara dan Pergeseran Kekuasaan dalam UUD 1945 (Yogyakarta: FH UI Press, 2005), hlm. 80.
} 
g) Tentang jabatan Wakil Presiden dalam negara kesatuan selama sebelum Konstituante terbentuk, Pemerintah Republik Indonesia Serikat dan Pemerintah Republik Indonesia akan mengadakan tukar pikiran lebih lanjut. (Pasal $45 \mathrm{dst}$ )

h) Dewan Pertimbangan Agung dihapuskan.

Seperti halnya Undang-Undang Dasar sebelumnya, Undang-Undang Dasar Sementara (UUDS) juga bersifat sementara. Ini terlihat dalam pasal 134 "Konstituante (sidang pembuat Undang-Undang Dasar) bersama-sama Pemerintah selekas-lekasnya menetapkan UndangUndang Dasar Republik Indonesia yang akan menggantikan Undang-Undang Dasar ini”. Seperti Konstitusi RIS, pembentuk Undang-Undang Dasar Sementara juga merasa belum representatif untuk menetapkan sebuah undang-undang. Undang-Undang Dasar Sementara ini hanya sekedar memenuhi kebutuhan karena ada perubahan dari bentuk federal menjadi kesatuan. UUDS ini dikemudian hari akan membentuk sebuah Badan Konstituante yang bersama Pemerintah akan membentuk sebuah Undang-Undang Dasar yang tetap.

Berdasarkan hasil pemilihan umum (Undang-Undang Dasar No.7 1953) Konstituante dilantik oleh Presiden 10 November 1956. Dalam Undang-Undang Dasar Sementara juga menganut sistem Kabinet Parlementer. Presiden sebagai kepala negara (pasal 45) bukan Kepala Pemerintahan.

\section{E. Undang-Undang Dasar 1945 Amandemen}

Pada tahun 1951 terdapat kurang lebih 27 partai politik bahkan setelah pemilihan umum diadakan dalam Badan Konstituante terdapat 35 fraksi. Badan Konstituante dilantik pada tanggal 10 November 1956, Badan ini bersama dengan Pemerintah menetapkan Undangundang Dasar yang akan menggantikan Undang-Undang Dasar Sementara. Setelah Badan ini bersidang kira-kira $21 / 2$ tahun lamanya ternyata belum dapat menghasilkan sebuah UndangUndang Dasar. Hal ini dikarenakan perbedaan pendapat yang sangat banyak diantara partai politik. Untuk mengatasi hal ini maka timbullah ide untuk melaksanakan "Demokrasi Terpimpin”, yang dianggap sesuai dengan kepribadian bangsa Indonesia. Untuk melaksanakan Demokrasi Terpimpin ini tidak mungkin mempertahankan Undang-Undang Dasar Sementara karena menganut asas Demokrasi Liberal.

Pada hari Minggu 5 Juli 1959 Soekarno selaku Presiden Republik Indonesia/Panglima Tertinggi Angkatan Perang mengeluarkan dekrit yang menyatakan bahwa terhitung mulai hari 
tanggal penetapan dekrit itu Undang-Undang Dasar 1945 berlaku lagi bagi segenap bangsa Indonesia dan seluruh tumpah darah Indonesia dan tidak berlakunya UUDS, hal ini dilakukan atas nama seluruh rakyat Indonesia. Ini dilakukan karena melihat situasi bangsa dalam keadaan tidak baik. Sejak saat itu Presiden tidak hanya sebagai Kepala Negara tetapi juga berfungsi sebagai Kepala Pemerintahan (fungsi eksekutif). Presiden adalah penyelenggara pemerintahan Negara yang tertinggi dibawah Majelis Permusyawaratan Rakyat. Oleh karena Soekarno awalnya adalah Presiden berdasarkan Undang-Undang Dasar Sementara yang berfungsi sebagai Kepala Negara maka pada tanggal 10 Juli 1959 beliau disumpah lagi sebagai Presiden berdasarkan Undang-Undang Dasar 1945. Bersamaan pada hari itu, Presiden Soekarno mengumumkan susunan nama-nama Menteri di Kabinet baru, yang terdiri dari para Menterimenteri berdasar Undang-Undang Dasar 1945. Menteri-menteri adalah pembantu Presiden yang diangkat dan diberhentikan oleh Presiden. Menteri-menteri tidak lagi bertanggung jawab kepada Dewan Perwakilan Rakyat tetapi kepada Presiden.

DPR yang sudah ada hasil Pemilu berdasarkan UU No. 7 tahun 1953, untuk sementara masih diberi wewenang menjalankan tugasnya menurut UUD 1945 melalui Penetapan Presiden No. 1 tahun 1959. Karena tidak sesuai dengan semangat dan jiwa Undang-Undang Dasar 1945 Demokrasi Terpimpin dan Manifesto politik Republik Indonesia maka presiden menetapkan melalui Penetapan Presiden No.3 tahun 1960 tentang "Pembaharuan susunan Dewan Perwakilan Rakyat", yang disebut dengan Dewan Perwakilan Rakyat Gotong Royong (DPR GR). Majelis Permusyawaratan Rakyat (MPR) diatur dalam Penetapan Presiden No.2 tahun 1959 tentang "Majelis Permusyawaratan Rakyat Sementara" yang lebih lanjut dikeluarkan Peraturan Presiden No. 12 tahun 1960 tentang "Susunan Majelis Permusyawaratan Rakyat Sementara”. Majelis Permusyawaratan Rakyat tediri dari anggota-anggota Dewan Perwakilan Rakyat ditambah utusan tiap daerah dan golongan-golongan. ${ }^{6}$ Selain itu melalui Dekrit Presiden 5 Juli dibentuk Dewan Pertimbangan Agung Sementara melalui Penetapan Presiden No.3 tahun1959. Dewan Pertimbangan Agung Sementara diangkat dan diberhentikan oleh Presiden, anggotanya terdiri dari golongan-golongan karya, politik, daerah, nasional.

Perubahan (Amandemen) UUD 1945 dilakukan oleh MPR Periode 1999 - 2004 dalam 4 tahap, tahap pertama 19 Oktober 1999, tahap kedua 18 Agustus 2000, tahap ketiga 9 November 2001, tahap keempat 10 Agutus 2002, berdasarkan pada ketentuan UUD 1945 yang berlaku sesuai Pasal 37 UUD 1945. Pada perubahan tahap pertama MPR masih menyebutkan “mengubah" Pasal-pasal UUD 1945, pada tahap kedua dan ketika disebutkan "mengubah

${ }^{6}$ Saragih, Bintan. Op.Cit. 
dan/atau menambah" Pasal-pasal UUD 1945 yang maknanya tetap sama yaitu baru sekedar perubahan. Pada tahap keempat, MPR tidak lagi sekedar mengubah dan menambah Pasal-pasal UUD 1945 tetapi sudah "menetapkan" Undang-Undang Dasar, hal tersebut dapat dilihat "setelah mempelajari, menelaah dan mempertimbangkan dengan seksama dan sungguhsungguh hal-hal yang bersifat mendasar yang dihadapi oleh rakyat, bangsa dan negara serta dengan menggunakan kewenangannya berdasarkan Pasal 3 dan Pasal 37 Undang-Undang Dasar Negara Republik Indonesia Tahun 1945, Majelis Permusyawaratan Rakyat Republik Indonesia menetapkan Undang-Undang Dasar dan Garis-Garis Besar Haluan Negara”.

Dasar pemikiran yang melatarbelakangi dilakukannya perubahan UUD 1945 diantaranya adalah ${ }^{7}$ :

a. Mencakup tuntutan Reformasi 1998:

1. Amandemen UUD 1945;

2. Penghapusan Dwi Fungsi ABRI;

3. Penegakan Supremasi Hukum, penghormatan HAM, dan pemberantasan $\mathrm{KKN}$;

4. Desentralisasi dan hubungan yang adil antara Pusat dan Daerah atau Otonomi Daerah;

5. Mewujudkan kebebasan Pers;

6. Mewujudkan kehidupan demokrasi.

b. Struktur ketatanegaraan menurut UUD 1945, bertumpu pada kewenangan atau kekuasaan tertinggi di tangan MPR yang sepenuhnya melaksanakan kedaulatan rakyat, dengan akibat tidak terjadinya checks and balances antar lembagalembaga kenegaraan.

c. UUD 1945 menganut sistem executive heavy yang berarti kewenangan atau kekuasaan dominan berada di tangan Presiden (eksekutif) dalam menjalankan pemerintahan atau chief exevutive yang dilengkapi dengan berbagai hak konstitusional yang lazim disebut hak prerogatif, antara lain memberi grasi, amnesti, abolisi, dan rehabilitasi serta wewenang legislatif sebagai penyebab tidak berfungsinya prinsip checks and balances dan mendorong lahirnya wewenang yang otoriter.

${ }^{7}$ Susilo Suharto, Kekuasaan Presiden RI dalam Periode Berlakunya UUD 1945 (Yogyakarta: Graha Ilmu, 2006), hlm. 139-141. 
d. UUD 1945 didalamnya terdapat pasal-pasal yang terlalu luwes yang dapat menimbulkan multi-tafsir.

e. Presiden diberi wewenang terlalu banyak oleh UUD 1945 untuk mengatur halhal penting dengan undang-undang. UUD 1945 menetapkan Presiden juga sebagai pemegang wewenang legislatif, sehingga Presiden dapat merumuskan hal-hal penting sesuai dengan kehendaknya dalam undang-undang. Hal ini menyebabkan pengaturan mengenai MPR, DPR, BPK, MA, HAM dan Pemerintahan Daerah disusun oleh wewenang Presiden dalam bentuk pengajuan rancangan undang-undang ke DPR.

f. Semangat penyelenggara negara yang dirumuskan di dalam UUD 1945 belum cukup didukung ketentuan konstitusi yang memuat aturan dasar tentang kehidupan yang demokratis, supremasi hukum, perberdayaan rakyat, penghormatan HAM dan otonomi daerah;

g. UUD 1945 bersifat ambivalen atau mendua, menganut sistem Presidensiil, akan tetapi Presidensiilnya tidak nyata, sebab Presiden harus bertanggung jawab pula kepada MPR yang berarti menganut sistem Kabinet Parlementer, jadi Presidensiilnya semu atau quasi Presidensiil.

Perubahan pertama berlaku mulai 19 Oktober 1999 yang meliputi sembilan Pasal (1) Pasal 5, tentang hak Presiden untuk mengajukan rancangan UU; (2) Pasal 7, tentang masa jabatan Presiden dan Wakil Presiden; (3) Pasal 9, tentang ketentuan sumpah atau janji jabatan Presiden/Wakil Presiden; (4) Pasal 13, tentang pengangkatan duta untuk negara lain dan penerimaan penempatan duta untuk negara Indonesia; (5) Pasal 14, tentang hak Presiden untuk memberi grasi, rehabilitasi, amnesti dan abolisi; (6) Pasal 15, tentang hak Presiden untuk memberi gelar, tanda jasa dan lain-lain tandan kehormatan; (7) Pasal 17, tentang MenteriMenteri pembantu Presiden; (8) Pasal 20, tentang kekuasaan legislasi DPR; dan (9) Pasal 21, mengenai hak anggota DPR untuk mengajukan usul rancangan UU.

Perubahan kedua berlaku mulai 18 Agustus 2000 meliputi 25 Pasal dan 5 Bab yang mencakup hal-hal:

1. Tentang Pemerintahan Daerah, 3 Pasal;

2. Tentang Dewan Perwakilan Rakyat, 5 Pasal;

3. Tentang Wilayah Negara, 1 Pasal;

4. Tentang Warga Negara dan Penduduk, 2 Pasal;

5. Tentang HAM, 10 Pasal; 
6. Tentang Pertahanan dan Keamanan Negara, 1 Pasal;

7. Tentang Bendera, Bahasa dan Lambang Negara, 5 Pasal.

Perubahan ketiga berlaku mulai 9 November 2001, meliputi 23 Pasal dan 3 Bab, mencakup kedaulatan, tata negara hukum, wewenang MPR, Presiden dan Wakil Presiden, DPR, Pemilu, APBN, BPK, Kekuasaan Kehakiman, Komisi Yudisial, dan Mahkamah Konstitusi. Pada perubahan keempat berlaku mulai 10 Agustus 2002 mencakup:

1. UUD 1945 sejak ditetapkan pada tanggal 18 Agustus hingga saat ini, telah mengalami banyak perubahan, baik oleh praktek ketatanegaraan RI sebanyak empat kali, maupun oleh MPR sebanyak empat kali;

2. Setelah perubahan keempat atas UUD 1945 oleh MPR, maka;

a. UUD 1945 tidak lagi bersifat sementara, walaupun hanya mempunya nilai sejarah, sebab meskipun UUD 1945 bersifat tetap, pasal-pasalnya masih dapat diadakan perubahan berdasarkan Pasal 37 UUD 1945;

b. UUD 1945 terdiri dai Pembukaan dan Pasal-Pasal. Penjelasan UUD 1945 ditiadakan, alasannya untuk menghindari kesulitan dalam menentukan status penjelasan dari sisi sumber hukum dan tata urutan peraturan perundang-undangan;

c. Khusus mengenai bentuk Negara Kesatuan Republik Indonesia, tidak dapat dilakukan perubahan;

d. MPR terdiri dari anggota DPR dan anggota DPD yang dipilih melalui Pemilu.

Menurut Pasal 37 UUD 1945, usul perubahan pasal-pasal UUD harus diajukan oleh sekurang-kurangnya 1/3 dari jumlah anggota MPR dan dihadiri sekurang-kurangnya 2/3 dari julmlah anggota MPR. Putusan untuk mengubah UUD harus disetujui sekurang-kurangnya 50\% dari seluruh anggota MPR. Meskipun telah dilakukan perubahan-perubahan dalam UUD 1945 namun tetap perlu ada perubahn-perubahan lebih lanjut yang akan menjadikan UUD 1945 lebih baik dan sistematis yang mencakup kehidupan religius, hukum, ekonomi, kehidupan demokrasi serta terhindar dari KKN. Tujuannya adalah agar terwujud kesejahteraan bagi seluruh bangsa Indonesia seperti yang terdapat dalam Pancasila.

Perubahan-perubahan yang terjadi dalam undang-undang dasar seyogianya adalah untuk kesejahteraan rakyat. Para elit politik merubah undang-undang disesuaikan dengan kondisi bangsa yang bersifat dinamis. Perubahan-perubahan yang terjadi tujuannya harus untuk kesejahteraan masyarakat Indonesia. Pengalaman panjang bangsa Indonesia merebut 
kemerdekaan dari tangan penjajah menjadi pelajaran penting bagi para wakil rakyat untuk benar-benar serius menganalisis, membuat undang-undang agar tidak berpihak kepada golongan atau kepentingan tertentu. Soekarno pernah mengucapkan "Jas Merah; jangan sekalikali melupakan sejarah", ini menjadi sebuah ingatan bagi para elite politik bangsa bahwa membuat undang-undang, peraturan haruslah melihat, belajar dari perjalanan bangsa Indonesia sehingga seyogiyanya menghasilkan aturan baru untuk kepentingan bangsa.

\section{Daftar Literatur:}

Kansil,dkk. 2001. Konstitusi-Konstitusi Indonesia Tahun 1945-2000. Jakarta: Pustaka Sinar Harapan

Jimly Ashiddiqie. 2005. Format Kelembagaan Negara dan Pergeseran Kekuasaan dalam UUD 1945. Yogyakarta: FH UI Press

Joeniarto. 2001. Sejarah Ketatanegaraan Republik Indonesia. Jakarta: Bumi Aksara

Ricklefs. 2005. Sejarah Indonesia Moderen 1200 -2004. Jakarta: Serambi

Suharto, Susilo. 2006. Kekuasaan Presiden RI dalam Periode Berlakunya UUD 1945. Yogyakarta: Graha Ilmu

Saragih,Bintan. Perubahan,Penggantian dan Penetapan Undang-undang Dasar di Indonesia. 2006. Bandung: CV Utomo

Undang-Undang Dasar 1945, Konstitusi RIS 1949, UUD Sementara 1950, dan UUD 1945 Amandemen. 